Krisztián Manzinger,

Péter Wagner

\title{
SYRIAN KURDS,
}

ROJAVA AND ALTERNATIVE

SOCIETY BUILDING

IN MIDDLE EAST

\author{
DOI: 10.35926/HDR.2020.1.2
}

ABSTRACT: Answering to local expectations and the need for a reliant partner for the US Army in the fight against ISIS, a Kurdish-based de facto autonomous territory emerged in Northern Syria, which later turned into a multicultural entity. The characteristically leftist political, social, and economic changes implemented by the new regime differ considerably from the government models practised in the region; however, they also trigger significant criticism. Although in 2018 and 2019, the entity suffered important losses in territory due to the geopolitical interests of Russia, the US, and Turkey, the Autonomous Administration of North and East Syria still could be a solid pillar in Syria's future. This is not only due to its strategic and military importance, but also because the political system could provide, nevertheless, after some changes, an alternative for the Middle East in terms of multicultural governance, women's rights and society-building based on mutual respect.

KEYWORDS: Nation-building, Syria, Kurds, Society-building, Self-governance, Middle East, Turkey, civil war

\section{INTRODUCTION}

The social, political and economic landscape of the Middle East has been reshaped by conflicts like the ongoing one in Syria. This civil war has created at least four different models of society building in one country, out of which this paper would like to examine the one implemented in the northern region. The aim of this paper is to present the distinct socio-economic model invigorated there, and the geopolitical challenges the model faces and creates.

To this end, Section I. presents the main characteristics of the Kurdish population generally, while Section II. focuses on the Kurds living in Syria and their history before the Arab Spring. Section III. shows the main features of the socio-economic changes implemented in Northern Syria after the Syrian regime's withdrawal. Section IV. briefly describes Damascus' approach towards Rojava, while Section V. presents the Turkish perspective of the ongoing community-building. Section VI. concludes and gives some perspectives regarding the future of the territory. 


\section{KURDS - A COMMUNITY IN A STRATEGIC PERIPHERAL LAND}

Rojava, West in Kurdish, is the colloquial name to describe the de facto autonomous region in Northern Syria, officially called Rojava-Democratic Federation of Northern Syria. The territory is the southward extension of the Kurdish populated area in Turkey. ${ }^{1}$ Kurds, who number around 30 to 40 million, are deemed to be the biggest nation on earth without a state of their own.

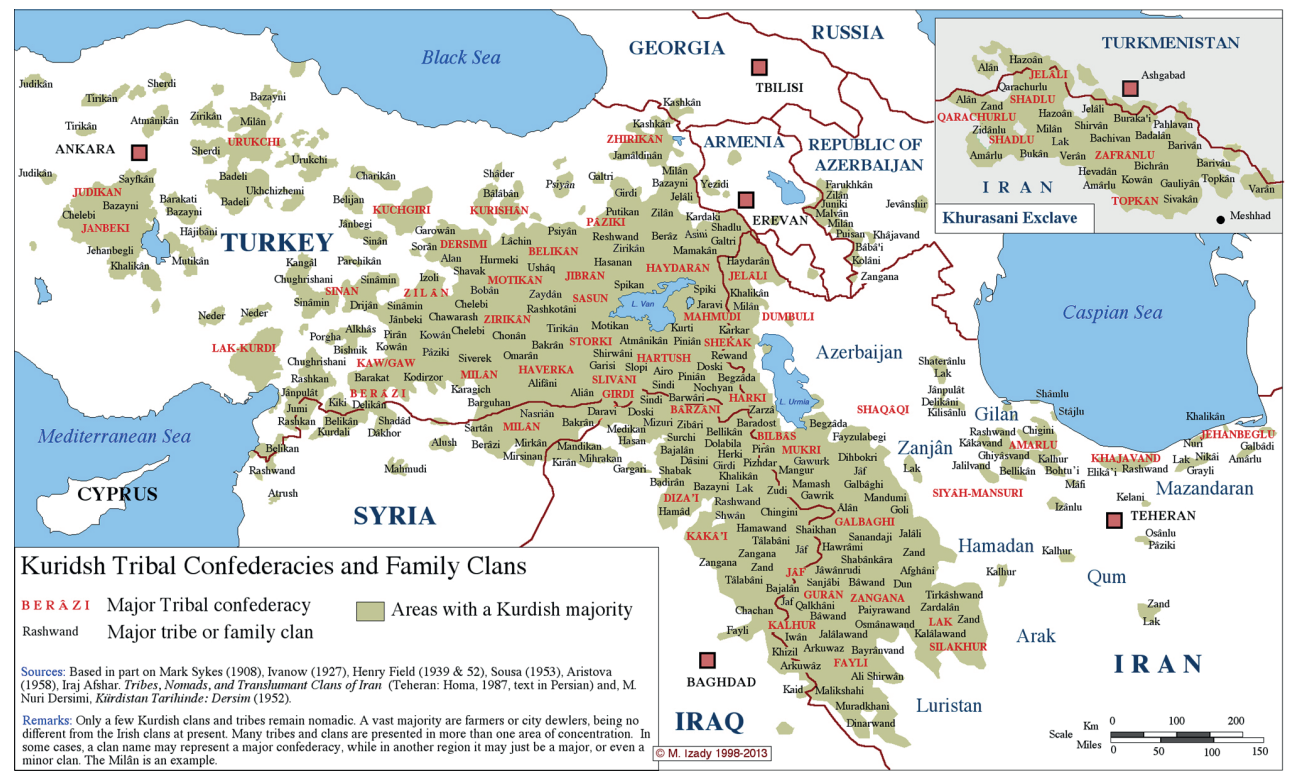

Map 1 Kurds in the Middle East ${ }^{2}$

The region inhabited by the Kurds is a peripheral one lying along the geopolitical fault line between the power centres in the Middle East. Nevertheless, keeping positions in Kurdistan is a major goal for all these countries, not only because of prestige, but also due to the fresh water and oil resources there. However, the borders separating Kurds were permeable for centuries, permitting not only a vivid economic cooperation between the different tribes, but also providing refuge in case of need. In the last decades, frontiers became more secured, protected by wire-mesh fences, minefields and air surveillance, reducing crossing only to authorized points and persons. Nevertheless, this feature faded to a certain extent as regional instability grew. The fight against the Islamic State (ISIS) have proved that cooperation among the communities on the different sides of the border is still alive.

Some argue that there is no single Kurdish nation. Taking Andersons's definition for the nation: 'an imagined and sovereign community limited from other nations', ${ }^{3}$ there

1 Vanly, I. Ch. "The Kurds in Syria and Lebanon". In Kreyenbroek, Ph. G. and Sperl, S. (eds), The Kurds: A Contemporary Overview. London, New York: Routledge, 2005. 113.

2 “The Feyli Kurds of Iraq", https:/ethnicgeography.wordpress.com/2013/10/07/the-feyli-kurds-part-3-the-feylikurds-of-iraq/, Accessed on 24 January 2020.

3 Anderson, B. Imagined Communities. London, New York: Verso, 2006. 6-7. 
could be counter arguments that Kurds meet these criteria. The Kurdish language itself is derived from the ancient Median language and is divided now into three main groups, the Northern (Kurmanji), the Central (Sorani) and the Southern (Pehlewani); nevertheless, millions of Kurds speak Zaza and Gorani as mother tongue. Due to historical reasons, not only the dialects differ but also the alphabet, according to the country Latin, Arab, Persian and even Cyrillic alphabets are used. The Kurmanji, spoken mostly by Kurds in Turkey and Syria, is the language of around two thirds of the Kurdish population and is official in Rojava and Iraqi Kurdistan; however, in the latter the majority speak Sorani. ${ }^{4}$ Despite their territories having been integrated into various countries for almost one hundred years, or in the case of Iran even more, there has been a growing tendency of considering Kurds from other regions' fellow-nationals. This has been strengthened by the existence of pan-Kurdish organizations, like the Kurdistan Workers' Party (PKK), the political cooperation of various Kurdish parties, and the rise of the self-governing territories in Iraq and recently in Syria.

Kurdish society is traditional; the role of clans is still an important point of reference. During the $19^{\text {th }}$ century, traditional Kurdish leaders were not interested in nationalism gaining ground fearing that that would undermine their power within the communities. ${ }^{5}$ In 1918 , there were great hopes for creating a Kurdish state, the Treaty of Lausanne in 1920 even generated an autonomous Kurdistan within Turkey with the option of holding a referendum on independence. Such hopes; however, vanished after the victory of Atatürk's army. After WWII, a short-lived Kurdish Autonomous Republic was created in Iran, which helped Kurdish language to gain ground in public spaces. Similar effects led to the establishment of the Kurdistan Region in Iraq and Rojava in Syria; however, these latter represent a more complex case of state and society building, due to their social, military and economic role and the weakness of the central states. The only Kurdish region without similar experience is the one belonging to Turkey, where there has been an ongoing armed conflict for independence, and later autonomy, between the state and the Kurdish insurgents affiliated with the PKK for decades.

Since the Treaty of Sevres in $1920,{ }^{6}$ until recently, Kurdish independence has not been seriously considered, mainly due to the complex geopolitical reality of the region. Despite the strong popular support to the PKK on the ground and its communist agenda, not even the Soviet Union supported their struggle for independence due to Moscow's regional interests. Although the PKK was provided support by various communist regimes eager to help the liberation cause elsewhere, none of them dared to get involved into the creation of Kurdish independence without the backing of the Soviet Union. ${ }^{7}$ The US wars against Iraq in 1990 and 2003 brought significant changes: Iraqi Kurdistan emerged as a self-governing region, distancing itself from Baghdad, and holding ultimately an unrecognized

4 On Kurdish see for instance "Kurdish Language". The Kurdish Project. https://thekurdishproject.org/history-and-culture/kurdish-culture/kurdish-language/, Accessed on 24 January 2020.; "The Kurdish language". Kurdistan Regional Government. http://cabinet.gov.krd/p/p.aspx?1=12\&p=215, Accessed on 24 January 2020.; "Kurdish (Kurdî / عدروى )". Omniglot. https://www.omniglot.com/writing/kurdish.htm, Accessed on 24 January 2020.

5 McDowall, D. A Modern History of the Kurds. London, New York: I.B. Tauris, 2007. 467-468.

6 The first peace treaty signed with Turkey after WWI, revised by the Treaty of Lausanne in 1923, after the Turkish War of Independence.

7 “A Mountain River Has Many Bends". Tangled Wilderness. 13. March 2015. http://www.tangledwilderness. org/a-mountain-river-has-many-bends/, Accessed on 24 January 2020. 
referendum on independence on 25 September 2017, when the overwhelming majority supported independence. Despite the referendum, the cooperation between Baghdad and Erbil did not end; however, the town of Kirkuk and its surrounding - occupied in 2012 after the collapse of the Iraqi Army - was retaken by Iraqi government forces as a consequence in October 2017.

\section{KURDS IN SYRIA BEFORE THE ARAB SPRING}

According to various estimations, Kurds make up around 8-10\% of the Syrian population, constituting the largest minority and the only one having a specific territorial base. This feature allowed them to form a region of their own after the withdrawal of the Syrian regime in 2012. Unlike in Iraqi Kurdistan, in Syria there was neither prelude to Rojava ${ }^{8}$ nor official use of Kurdish, and in Turkey, Syrian Kurds had no possibility to rebel against the state oppression due to the lack of proper conditions for a guerrilla warfare.

Nevertheless, Kurdish population has been autochthonous in Rojava since the $11^{\text {th }}$ century; many of the Syrian Kurds are descendants of those who fled Turkey in the 1920s, after a Kurdish rebellion was crashed there. Their influx soon resulted in transforming the region into a rear base for anti-Turkey Kurdish activity, however, the then acting French administration discouraged any political or military move against the northern neighbour. ${ }^{9}$ Yet, the French contributed to the strengthening of the minority identity in order to weaken the Sunni Arab majority in Syria. ${ }^{10}$

After Syria gained independence, due to the lack of trust and because of the diverging visions on the future, Kurds became a minority treated unfavourable. The situation worsened with the spread of the Arab nationalism in the 1950s. ${ }^{11}$ After 1946, the first organization to overcome discrimination was the unrecognized underground Kurdish Democratic Party of Syria, established in 1957, with the aim of ensuring Kurdish linguistic and cultural rights, economic development and democratization of the Syrian political life. Yet, the exclusion and pauperization of the Kurds resulted in the fact that many of the intellectuals subordinated nationalist feelings to class struggle and Kurds achieved a disproportionately large representation within the Communist Party of Syria. ${ }^{12}$

After declaring the Syrian Arab Republic in 1961, life became even harder: a state organized campaign unfolded against Kurds. The change was related to the discovery of the oil resources in the northeast region of Syria and the Iraqi Kurdistan uprising. A particularly important document was a decree in 1962, which deprived around 120,000 Kurds, or 20 percent of the Syrian Kurds of Syrian nationality. ${ }^{13}$ In 1963, Damascus joined Iraq in its war against Iraqi Kurdistan, further deteriorating Arab-Kurdish relations within Syria. Syrian officials considered Kurdish attempts in northern Iraq dangerous as the then head of the Syrian

8 In the 1930s, there was an attempt to gain autonomy for al-Jazira province, however, turned down by the French authorities. Gorgas, J. T. "Les territoires de marge de la Syrie mandataire : le mouvement autonomiste de la Haute Jazîra, paradoxes et ambiguités d'une intégration «nationale » inachevée (1936-1939)". Revue des mondes musulmans et de la Méditerranée 2. 2009. DOI:10.4000/remmm.6481, Accessed on 24 January 2020.

9 Vanly. "The Kurds in Syria and Lebanon". 117.

10 This proved to be useful when crushing the revolt against the French rule in 1925.

11 Tejel, J. Syria's Kurds: History, Politics and Society. London, New York: Routledge Taylor \& Francis Group, 2009. 48

12 McDowall. A Modern History of the Kurds. 472.

13 On the process see Tejel. Syria's Kurds. 49-52. 
secret service in Al-Hasakah compared the Kurdish cause to the example of Israel in a document compiled for the government, arguing that while Israel was an 'imperialism'-created fait accompli for the Arab world, Kurdistan, a second 'Judastan' could be the same made by 'communists'. ${ }^{14}$ Nevertheless, the disclosure of the plan generated indignation, Syrian Kurdish political parties recognized the importance of wording and since the 1970s they have dropped the term 'Kurdistan' and use the word 'Kurdish' instead. ${ }^{15}$

In order to weaken Kurdish presence forced Arabization, deprivation of citizenship and property, and removal of population became practice in the Syrian-Turkish border region. ${ }^{16}$ For instance, in 1973 and 2007, Syrian authorities confiscated Kurdish owned arable lands and gave them to Arab families brought from other parts of the country to change the ethnic composition. ${ }^{17}$ When the settlement program was stopped in 1976, there were already 41 new villages in the hizami al- 'arabi, the 'Arab Belt' for settlers. ${ }^{18}$ Nevertheless, despite these attempts, the territory remained mostly Kurdish populated, and the overwhelming majority of the Kurds monolingual, unable to speak Arabic. ${ }^{19}$

During the reign of Hafez al-Assad, in the eyes of the Sunni Arab majority Kurds became allies of the oppressing regime, because they contributed to the repression of the Sunni revolts in the $1980 \mathrm{~s} .{ }^{20}$ However, on the contrary, Kurds were generally not favoured, and the 1980s and 1990s saw further regulations to suppress Kurdish language and identity, although some Kurds were co-opted by the regime during Hafez al-Assad's reign. ${ }^{21}$ This oppression had not changed prior to the Arab Spring, and the existence of tensions became visible by such events like the Qamishlo uprising in 2004. ${ }^{22}$

As Kurds live in four countries, they have frequently been subjects of or partners in foreign involvement into the affairs of the neighbouring states. While in the 1960s Damascus helped Baghdad in a war against Iraqi Kurdistan; in the 1980s they sided with Iraqi Kurdistan against Baghdad due to the disputes between al-Assad and Iraqi leader Saddam Hussein. Syria also provided shelter for the reorganization of and recruitment to the PKK after the group had to flee Turkey following the military coup there in $1980 .{ }^{23}$ This help was so important, that in 1996 PKK-leader Abdullah Öçalan openly declared that Syria

14 Vanly. "The Kurds in Syria and Lebanon". 121-122.

15 McDowall. A Modern History of the Kurds. 478.

16 "Syria-The Silenced Kurds". Human Rights Watch Reports 8/4. 1996. https://www.hrw.org/reports/1996/Syria. htm, Accessed on 24 January 2020. Between 1954 and 1961, the population of Hasakah province grew by 27 percent, which cannot be explained merely by natural increase. McDowall. A Modern History of the Kurds, 473.

17 "Persecution and Discrimination against Kurdish Citizens in Syria". Office of the United Nations High Commissioner for Human Rights. http://lib.ohchr.org/HRBodies/UPR/Documents/session12/SY/KIS-KurdsinSyria-eng.pdf, Accessed on 24 January 2020.

18 McDowall. A Modern History of the Kurds. 475.

19 Vanly. "The Kurds in Syria and Lebanon". 116.

20 Vanly. "The Kurds in Syria and Lebanon". 125.; McDowall. A Modern History of the Kurds. 477.

21 Tejel. Syria's Kurds. 65-68.

22 On 12 March 2004, after atrocities at a soccer match between the Kurdish supporters of Qamishlo and the Arab supporters of Deir Ez-Zor during which the Syrian security forces acted against the Kurds, killing six people, including three children, Kurdish protesters burned down the local Ba'ath Party office and toppled the statue of Hafez al-Assad. After the events the Syrian Army recaptured the town, killing over 30 Kurds, and arresting 2,000, while many Kurds fled for KRG in Iraq.

23 The popular support for the PKK was extremely strong in Kobanî and in the Kurd Mountains - today Afrin region - in north-western Syria. Allsopp, H. The Kurds of Syria. Political Parties and Identity in the Middle East. I.B. Tauris, 2015. 103. 
had no Kurds of its own and those living there were all refugees from Turkey. ${ }^{24}$ The Syria-PKK cooperation lasted until 1998, when Turkey managed to achieve the break of that, with strengthening the relations with Israel, and threatening Damascus with a military intervention..$^{25}$

\section{ROJAVA - A COMMUNITY-BUILDING PROJECT}

As Syrian authorities withdrew from the Kurdish regions in August 2012, when the battle for Aleppo started, control remained to local forces. The already existing underground Democratic Union Party (PYD) and the Kurdish National Council (KNC) formed the Kurdish Supreme Committee (KSC) for governing and administrating the territory and the PYD-affiliated People's Protection Units (YPG) became the force of armed self-defence. Later PYD renounced cooperation with $\mathrm{KNC}$ after the latter, in close cooperation with the Iraqi Kurdistan, whose President, Massud Barzani is a partner of Turkey, insisted on sharing power within Rojava, and tried to form its own militia, a rival to YPG. Since then, the KNC, supported by Turkey and Saudi Arabia, has been strongly opposing the existence of the autonomous administration, similarly to the Syrian National Council (SNC). ${ }^{26}$

However, states and political scientists generally reject the idea of territorial autonomy in the third world because it impedes 'nation-building', and is therefore 'retrogressive'. Some scholars agree that as most states do grant neither collective nor individual human rights and communities are not protected against state abuse, autonomy should be provided where it serves justice and human dignity, since then it is 'progressive'. ${ }^{27}$ In strengthening the international recognition of the PYD and that of the YPG, the siege of Kobanî was a turning point. Then, at the peak of the ISIS, US policymakers impressed by the local resistance established working relations with the YPG.$^{28}$ As the US program to train and equip Syrian rebels to fight ISIS had proven to be a failure by that time, the YPG managed to stabilize its position as a reliable ally of Washington. Alongside the war against ISIS, another articulated US goal was the promotion of democracy in the MENA region. ${ }^{29}$ This also largely resonated with the developments in Rojava, where the situation developed compared to the previous administration, even if some call that 'a new form of a decentralized non-state government

24 McDowall. A Modern History of the Kurds. 479-480.

25 Cagaptay S. "Syria and Turkey: The PKK Dimension". The Washington Institute. 5 April 2012. http://www. washingtoninstitute.org/policy-analysis/view/syria-and-turkey-the-pkk-dimension, Accessed on 24 January 2020 .

26 In the beginning the SNC, formed in Istanbul on 23 August 2011, was hoped to become a Syrian government in exile. Such hopes failed; however, many countries have recognized it as a partner, although Kurds have barely been involved into the SNC: only the small party of Kurdish Future Movement in Syria is represented. A member of the Kurdish Future Movement, also a member of the city council in Darbasiyah in Jazira, was arrested by the PYD administration on 1 April 2017. "Member of the Kurdish Future Movement arrested by Kurdish Self-management forces in al Darbasiya city in Hasaka governorate on April 1". Syrian Network for Human Rights. 1 April 2017. http://sn4hr.org/blog/2017/04/01/member-kurdish-future-movement-arrested-kurdish-self-management-forces-al-darbasiya-city-hasaka-governorate-april-1/, Accessed on 24 January 2020.

27 Safran, W. "Spatial and Functional Dimensions of Autonomy: Cross-national and Theoretical Perspectives". In Safran, W. and Máiz, R. (eds), Identity and Territorial Autonomy in Plural Societies. London, Portland: Frank Cass, 2000. 19-20.

28 Hassan, H. "The Battle for Raqqa and the Challenges after Liberation" CTC Sentinel 10/6. 2017. 2.

29 About the US policy in the Middle East see Echagüe, A. "The United States: redefining engagement?". In Kausch, K. (ed), Geopolitics and Democracy in the Middle East. Madrid: FRIDE, 2015. 181-193. 
without hierarchy', ${ }^{30}$ The ideological basis for the implemented social and economic changes stems from the thoughts of the imprisoned PKK leader Abdullah Öçalan, who is considered to be the spiritual leader of the PYD.

The growing military importance of the PYD and YPG had led to changes in how power is exercised in Rojava by the time they started to expand their control to territories populated by Sunni Arab majority. Those territories long opposed the Syrian regime because of being oppressed by Damascus and to some extent were supportive to the ISIS, regarding the terrorist group a guardian angel of Sunnis. As a consequence of this, a secular Kurdish rule would not have been an appropriate reason for Sunni Arabs to fight for or even to tolerate being subjugated to. Understanding the need for a change, as early as 2013, the PYD called for the creation of a progressive multi-ethnic region in wider Rojava, beyond the ethnic borders of the Kurds. The change was reflected also in the constitution of 2014, unrecognized by Syria, and in the renaming of the territory to Rojava-Democratic Federation of Northern Syria, in December 2016.

As the political system changed, the military approach also had to be subjected to changes. The Syrian Democratic Forces (SDF) - a multi-ethnic and multi-religious alliance of Kurdish, Arab, Assyrian, Armenian, Turkmen and Circassian militias - was founded in October 2015, and declared the official defence force of Rojava by the December 2016 constitution. The SDF-US Army partnership has facilitated the cooperation between Kurd and Arab forces, because the latter started to see SDF and Rojava as an American project and a 'life insurance' since US military presence makes it difficult for Damascus to attack the liberated areas. ${ }^{31}$ Due to the growing share of non-Kurdish population in the extending territory of Rojava, the SDF cannot be considered any more "a subsidiary of the YPG" 32 , or simply a tool for Kurds to expand their influence in predominantly Arab areas. According to Pentagon estimations, in March 2017 the SDF was made of Kurd forces in 40 percent and Arabs in 60 percent. ${ }^{33}$ The role of women is also important: in 2016, they made up about 30 to 40 percent of the YPG in the Women's Protection Units (YPJ), ${ }^{34}$ while on 10 July 2017, the first Arab female battalion was organized on the outskirts of Raqqa. ${ }^{35}$

After the administrative reform of July 2017, Rojava-Democratic Federation of Northern Syria was composed of three regions, Jazira (Hasakah), Euphrates (Kobanî), and Afrin, while some territories under SDF control were not organized into them (in blue on Map 2). The Turkish interventions in 2018 and 2019 led to changes both in territory and administrative organization of the territory. The region was renamed to Autonomous Administration of

30 "A Mountain River Has Many Bends".

31 Hassan, H. "The Battle for Raqqa". 4.

32 "Global powers seek to revive diplomatic process". The Economist. 12 February 2016. http://country.eiu.com/ article.aspx?articleid=1363937520\&Country=Syria\&topic=Politics, Accessed on 24 January 2020.

33 "News Transcript of the Department of Defense Press Briefing by Gen. Townsend via teleconference from Baghdad, Iraq". US Department of Defence. 1 March 2017. https://www.defense.gov/News/Transcripts/Transcript-View/Article/1099469/department-of-defense-press-briefing-by-gen-townsend-via-teleconference-fromba/, Accessed on 24 January 2020.

34 Sido, K. "Rojava - a protection zone for religious and ethnic minorities in northern Syria?". Gesellschaft für bedrohte Völker. June 2016. https://www.gfbv.de/fileadmin/redaktion/Reporte_Memoranden/2016/Northern-Syria-research-trip-2016.compressed.pdf, 5. Accessed on 24 January 2020., Baumstieger, M. "Rojda Felat". Süddeutsche Zeitung, 8 November 2016. http://www.sueddeutsche.de/politik/profil-rojda-felat-1.3239571, Accessed on 24 January 2020.

35 "SDF creates female Arab battalion in eastern Syria to fight patriarchy and ISIS". Al Shahid. 12 July 2017. https://alshahidwitness.com/sdf-female-arab-battalion-eastern-syria/, Accessed on 24 January 2020. 


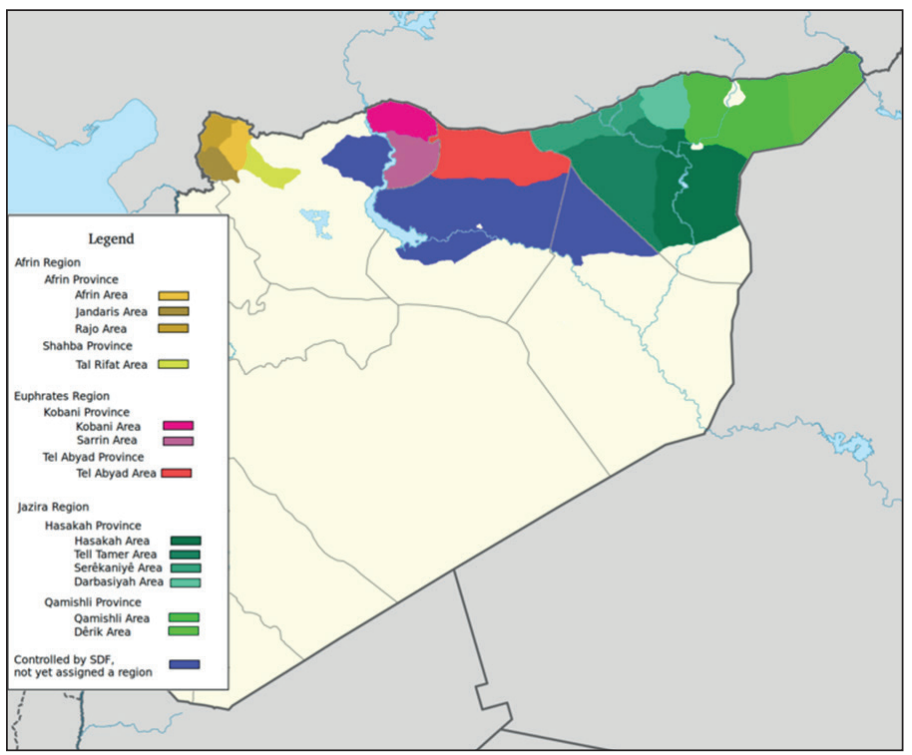

Map 2 The regions of Rojava in mid-2017

(Source: https://en.wikipedia.org/wiki/Democratic_Federation_of_Northern_Syria)

North and East Syria (NES), based on the regions of Jazira, Euphrates, and Afrin (despite the fact that the seat is occupied by Turkey), and local councils of Raqqa, Manbij, Tabqa, and Deir ez-Zor; under the leadership of the 70-member General Council, however, the power of the regions has decreased as seen on Map 3.

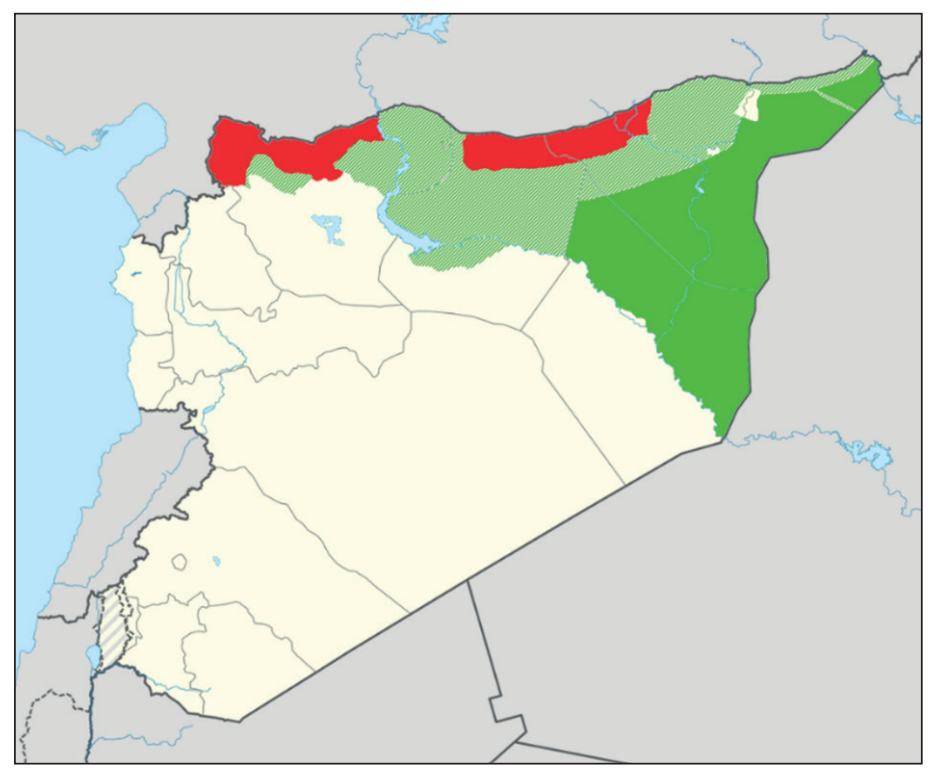

Map 3 NES in January 2020, dark green: SDF controlled territories, light green: SDF-control with Syrian military presence, red: Turkish-held territories

(Source: https://en.wikipedia.org/wiki/File:Claimed_and_de_facto_territory_of_Rojava.png) 
Regions, as parts of the structure of the Democratic Autonomous Administration (DAA), are seen to be similar to the Group of Communities in Kurdistan (KCK), established in 2005, to implement Öçalan's democratic confederal model in the regions of Kurdistan. The KCK is an institutionalized umbrella structure overseeing its member organizations: the PKK in Turkey, the PYD in Syria, the Kurdistan Democratic Solution Party in Iraq and the Kurdistan Free Life Party in Iran, nevertheless, leaving them a great room for manoeuvre or autonomy. ${ }^{36}$ The DAA system in Rojava covers the three regions, comprises their legislative, judicial and executive councils and one general coordinating council acting for all the cantons. Each region has a government, which while ensuring cooperation with the others, implements its own policy and provides services. Policing is provided by the Asayish ('security' in Kurdish), a force organized in the regions. There is no federal government in Rojava.

A guideline elaborated by Öçalan and implemented by the SDF is the vision of the 'democratic nation' according to which all ethnic groups must participate in the local government. The main political force of Rojava is the Movement for a Democratic Society (TEV-DEM) a multi-ethnic, leftist coalition, in which the PYD has a crucial role but which includes Arab, Turkmen, Assyrian and further Kurdish forces; however, all of them allied with the PYD. Practically, this means that although decentralized institutions are being built, power is heavily centralized in the hands of the PYD. ${ }^{37}$ As political views diverging from that of the PYD are excluded, the system implemented is not inclusive in the sense of political diversity.

After decades of Arabization, the current administration shows respect to multilingualism: the authorities commonly use three languages, Arabic, Kurdish written with Latin alphabet, and Aramaic. ${ }^{38}$ Official signs of the administration and street signs in Christian villages are trilingual..$^{39}$ Peaceful ethnic co-existence and the prevention of the alienation of the non-Kurdish elements of society are priorities; that is why the use of the flag of Kurdistan is not encouraged; however, officially not banned. ${ }^{40}$

The 2016 constitution is unique in the Middle East, as it recognizes gender equality, minority rights, direct democracy and strives for social equality, while prohibits among others polygamy, forced or underage marriage. Declared gender equality is almost unique in the region, women not only have equal rights, they form an important and recognized pillar of society and the military, too. A further implemented Öçalan guideline is that institutions must have both male and female leaders. These changes affect everyday life fundamentally. For illustrating this, the conservative, ethnically mixed and tribe-dominated, even largely ISIS-supportive town of Tell Abyad, previously subjected to forced Arabization, could have served as a blueprint. Before the Turkish invasion of 2019, two co-mayors, one of which a Kurdish woman in her late 20s, ran the town; while in the local council, with Arab majority,

36 Khalaf, R. M. Governing Rojava: Layers of Legitimacy in Syria. London: Chatham House, 2016. 10-11. https://www.chathamhouse.org/sites/default/files/publications/research/2016-12-08-governing-rojava-khalaf.pdf, Accessed on 24 January 2020.

37 Khalaf. Governing Rojava. 10.

38 An ancient language in the Middle East belonging to the Afro-Asiatic language family and the Semitic subfamily. The Aramaic, now endangered and spoken by several hundreds of thousand people, served as a lingua franca in the region for centuries.

39 Sido. "Rojava...". 22.

40 Khalaf. Governing Rojava. 23. 
the representation of the minorities was ensured. Teaching was provided in both Arabic and Kurdish instead of solely Arabic. ${ }^{41}$

The administration is not attempting to create a distinct political entity in Rojava: Syrian identity cards, documents, and currency are still used. Similarly, Syrian legal system is applied if there is no conflict with the regional constitution; however, a distinct court system has been created in which lower courts' decisions are made with the involvement of citizens, while at higher levels the participation of trained jurists is compulsory. ${ }^{42}$ Sharia is not practised as the leading principle is secularism in Rojava; however, the diminution of men's traditional domestic authority causes social unrest.

Decision-making is based on local communities, in accordance with traditions; decisions are made collectively and aspiring to unanimity. ${ }^{43}$ Due to security reasons, until today, there were only partial elections, ${ }^{44}$ but during the assignment of local leaders and councils some rules were respected. The councils already existed underground before the Arab Spring, when they were tools for the local population to solve problems on their own; however, these authorities were persecuted by the regime. ${ }^{45}$ After the autonomy was implemented, the councils became the backbone of the administration, assuring legitimacy and efficiency at the same time. Planned regional elections of 2014 and 2018 were postponed.

Primary and secondary education is free and carried out in mother tongue, in contrast to the Arabic-language instruction before 2012. However, the curriculum influenced by Öçalan's views is triggering criticism, and diplomas issued by the regional authorities are not recognized elsewhere. In September 2017, despite Damascus' approval, the PYD rejected the proposal of the UNICEF to take over the 2,000 schools operating in Hasakah in order to teach a standardized curriculum, as it turned down the intention to set up schools in the Al-Mabrouka displaced persons camp in rural Hasakah. ${ }^{46}$ Another issue emerged with the private schools first exempted from applying the regional curriculum. After some disputes in September 2018, a deal was achieved between the regional authorities and the local Syrian Orthodox archbishop, allowing for Assyrian private confessional schools to

41 Van Wilgenburg, W. "Young female mayor breaks boundaries in Syrian town freed from Islamic State". Middle East Eye. 1 July 2016. http://www.middleeasteye.net/in-depth/features/young-female-mayor-breaks-boundaries-syrian-town-freed-552711157, Accessed on 24 January 2020.; "They freed a Syrian town from ISIS. Now they have to govern it". The Washington Post. 30 October 2015. https:/www.washingtonpost.com/world/thechallenges-of-governing-after-the-islamic-state/2015/10/30/8985938c-7673-11e5-a5e2-40d6b2ad18dd_story. html?utm term=.5833e928052b, Accessed on 24 January 2020.

42 Ayboğa, E. "The new justice system in Rojava". 13 October 2014. http://www.biehlonbookchin.com/justice-system-in-rojava/, Accessed on 24 January 2020.

43 Baher, Z. "The Experiment of West Kurdistan Has Proved That People Can Make Changes" Co-operation in Mesopotamia. 12 March 2016. https://cooperativeeconomy.info/the-experiment-of-west-kurdistan-has-provedthat-people-can-make-changes/, Accessed on 24 January 2020.

44 That election took place in March 2015 in the then controlled mostly Kurdish populated area, amid the boycott of the KNC. Under the previous regime functionaries were chosen and nominated by the Baath Party.

45 Lebsky, M. "The Economy of Rojava" Co-operation in Mesopotamia. 14 March 2017. https://cooperativeeconomy.info/the-economy-of-rojava/, Accessed on 24 January 2020.

46 The reason in both cases was the non-implementation of the Rojava administration approved curriculum influenced by Öçalan's views. Al-Wasl, Z. "PYD Refuses UNICEF Proposal to Administer 2,000 Schools in Hassakeh". The Syrian Observer. 8 September 2017. https://syrianobserver.com/EN/news/22370/pyd_refuses_unicef_proposal_administer_schools_hassakeh.html, Accessed on 24 January 2020.; Khalaf. Governing Rojava. $1 \overline{8}$. 
teach in the first two grades the region's curriculum, and in grades three to six the Damascus-approved one. ${ }^{47}$

Higher education has also been created: a college providing teaching in Kurdish opened in Afrin in September 2015, ${ }^{48}$ while in Qamishlo the Rojava University opened in 2016, in cooperation with the Paris 8 University, with colleges of medicine, engineering, agricultural studies, communications and computer sciences, while the college of petroleum has been located in Rmelan city. After the Turkish invasion of Afrin in 2018, the college closed, however, in October 2019 it was announced that the University of Gaziantep, Turkey, would open faculties in the Northern Syrian towns of Afrin, Al-Bab and Azaz. ${ }^{49}$

Since the outbreak of the civil war the ethnic and religious composition of Syria has radically changed due to the exodus of many belonging to minorities and the arrival of internally displaced persons' (IDP) to certain areas, what is true for Rojava, as well. For instance, before 2011 there were some 50 Yazidi villages in Hasakah/Jazira province, many of them no longer inhabited. ${ }^{50}$ As population exchange has become practiced widespread by every administration in Syria, some fear that the installation of Rojava could lead to ethnic cleansing despite the official slogans. However, there have been some examples to this, for instance tens of thousands of Arabs left the mentioned Tell Abyad due to the fear of retribution when the YPG took it in $2015,{ }^{51}$ the general situation is the contrary, the number of the Arabs have doubled in Rojava since the beginning of the conflict, ${ }^{52}$ as many of the some 1.3 million IDPs in Rojava belong to that group. Another Arab fear is attached to the recruitment of military-age people from the region under Rojava control, which sporadically produces protests showing the lack of trust between the groups. The Turkish invasions of 2018 and 2019 have also altered the ethnic composition of the concerned regions, however reliable data is not available. What is known, for instance, is that in April 2018 a Kurdish-majority 'elders council' was established in Afrin, indicating that even the Turkish invaders considered the town a Kurdish-majority one. ${ }^{53}$ Yet, Amnesty International warned that Turkey and her allies were committing human rights violations in Afrin. ${ }^{54}$

After the Kurdish forces started to occupy non-Kurdish populated areas, a special administrative regime, the military council, was introduced. The first one to set up was the Manbij military council in April 2016, composed of Arabs, Kurds, Assyrians and Turkomans

47 Souleiman, D. "Syriacs protest Kurdish authorities over Syria school curriculum". Yahoo News. 12 September 2018. https://news.yahoo.com/kurds-christians-split-over-syria-school-curriculum-041427147.html, Accessed on 24 January 2020.

48 That was the first Kurdish-language higher education institution in Syria, and one of the main reasons for the creation was the commuting difficulties between Afrin and Aleppo due to the outbreak of the Civil War. Drwish, S. M. "Suriye'nin ilk Kürt üniversitesi tartışmalara neden oluyor". Al-Monitor. 18 May 2016. http:// al-monitor. com/pulse/tr/originals/2016/05/kurds-rojava-afrin-first-university-ideology-ocalan.html, Accessed on 24 January 2020 .

49 Erkoyun, E. "Turkish university to open faculties in northern Syria" Reuters. 4 October 2019. https://www. reuters.com/article/us-syria-security-turkey-education-idUSKBN1WJ0Z3, Accessed on 24 January 2020.

50 Sido. "Rojava...". 22.

51 "They freed...".

52 Sido. "Rojava...". 24.

53 “Interim local council established in Syria’s Afrin”. Hürriyet Daily News. 12 April 2018. http://www.hurriyetdailynews.com/interim-local-council-established-in-syrias-afrin-130227, Accessed on 24 January 2020.

54 "Syria: Turkey must stop serious violations by allied groups and its own forces in Afrin." Amnesty International. 2 August 2018. https:/www.amnesty.org/en/latest/news/2018/08/syria-turkey-must-stop-serious-violations-byallied-groups-and-its-own-forces-in-afrin/, Accessed on 24 January 2020. 
with the aim of administering the town and the region after being captured from the ISIS. The reason behind was that Manbij is not only of strategic importance, but is also an Arab-majority town with many ethnic groups, which made such a precaution necessary before the offensive. ${ }^{55}$ In August 2016, similar military councils were formed for Jarabulus and Al$\mathrm{Bab}$, both located in the neighbourhood of Manbij and taken by the Free Syrian Army (FSA) and the Turkish army in August 2016 and February 2017, respectively. The fourth military council was formed in December 2016 for Deir ez-Zor; however, the town's siege was lifted in September 2017 by the Syrian Army, leaving Deir ez-Zor out of Rojava.

After the liberation of Manbij, a Legislative Assembly was formed which in March 2017 created the Democratic Civilian Administration of Manbij and its Surroundings with two co-presidents to replace the military administration. ${ }^{56}$ The composition of the council, having 71 Arab, 43 Kurd, 10 Turkoman, 8 Circassian, 1 Armenian and 1 Chechen members, shows the multi-ethnic feature of the region, and is also a good example of the ethnic inclusion the new administration is eager to emphasize.$^{57}$ At first, the territory was incorporated into the Shahba region, created early in 2016, to administer the multi-ethnic territories between Afrin and Kobanî cantons; however, it was left outside the region system at the administrative reorganization in late July $2017 . .^{58}$

From economic point of view the territory and the population of Rojava was long discriminated against by the regime; however, Syria had to rely on Rojava as $70 \%$ of the wheat was produced there and also the oil extracted had an important share in the national production. These sources contributed substantially to the economic self-reliance of Rojava after the withdrawal of the Syrian state. ${ }^{59}$ While the other regions are predominantly agricultural, Jazira is an economic engine; however, oil-refineries had to be built there since before the war such industry was concentrated in other parts of the country. Afrin profited a lot from the devastation of Aleppo, a significant part of the famous soap industry found refuge there.$^{60} \mathrm{~A}$ major challenge was to rebuild water, electricity and road infrastructure, either destroyed during the war or collapsed after the withdrawal of the regime. ${ }^{61}$ Before capturing the Tabqa Dam in May 2017 and some minor dams earlier, electricity retailing

55 In 2019, following the withdrawal of US and other Western troops from northern Syria, the Syrian Army and Russian military police entered Manbij to prevent a Turkish and a Free Syrian Army offensive.

56 "Manbij Democratic Civilian Administration Council takes office". ANF News. 12 March 2017. https://anfenglish.com/news/manbij-democratic-civilian-administration-council-takes-office-18957, Accessed on 24 January 2020.

57 Some locals were complaining that the PYD dismantled the elected local council that had been operating prior to the ISIS occupation, and brought its own appointees historically linked to the regime and thus distrusted. Khalaf. Governing Rojava. 20.

58 After the administrative reorganization of Rojava in July 2017, Shahba was divided into two: the Tell Rifat area i.e. the western part of the region was incorporated into the Afrin region, while the Manbij area was left outside of the region system.

59 These also contributed to the survival of Rojava after a considerable number of IDPs arrived in the territory. According to the minister of economy of Afrin in 2014, Rojava can support a population two or three times larger than that lived there before the conflict. "Efrîn Economy Minister Yousef: Rojava challenging norms of class, gender and power”. DIHA. 22 December 2014. http://diclenews.com/en/news/content/view/436354, Accessed on 24 January 2020.

60 "Efrîn Economy Minister...".

61 Evran, S. "Efrin Is Being Rebuilt, Calls for Support and Investment" The Rojava Report. 6 May 2014. https://rojavareport.wordpress.com/2014/05/06/efrin-is-being-rebuilt-calls-for-support-and-investment/, Accessed on 24 January 2020. 
was also a major problem, but the possession of these dams helps to supply the region with electricity and drinking water.

The economic model implemented in Rojava is an agrarian form of socialism based on cooperatives. ${ }^{62}$ The economic policy is not aiming either a capitalist or a communist regime, but seeking a 'people's economy' based on cooperatives and communes, and provides general welfare and funding for science and technology. ${ }^{63}$ Banking is limited to handle savings and helping the communes; resource of financing is the output of the projects. ${ }^{64}$ Economic changes also resulted in the limitation of private property to two forms: personal (cars, electronic goods and personal belongings), and property based on direct use. The principle 'ownership by use' became the central idea, meaning that when a property is being used by a person or persons, the users own the land and structures but are not entitled to sell them on an open market. ${ }^{65}$

After the seizure of power and the abolishment of the right to large private property, around $2 / 3$ of the big property was 'socialised', i. e. put at the service of the population. ${ }^{66}$ Aside from property owned by use, in principle any other property became common, held in stewardship by councils that are entitled to turn over these public goods to individuals for use. Local councils manage some 3/4 of the land while in the case of industry this share is $1 / 3 .{ }^{67}$ Oil industry is under the control of the councils and managed by the workers' committees. Services like education, job provision-mainly in institutions-electricity, water, healthcare and security are provided by the Democratic Autonomous Administration (DAA) governance, the regions for a fee. In Hasakah parallel services are sometimes available, due to the existence of the regime enclaves. ${ }^{68}$

Regions and councils implement their own economic policy; however, there is an Institute for Economic Development, an authority that regulates import and export trade, issues trading licences to individuals and elaborates modernization projects for the agriculture and industry in Rojava. Planning is crucial as the economy is still relying on agriculture and has been hit by the embargo imposed by neighbours, nevertheless, the situation improved after Iraqi Kurdistan opened the border in June 2016. Everything produced in Rojava is inexpensive, as the economic model aims rather a social approach and redistribution of wealth than accumulation or creating a stock exchange. Other goods are brought from Iraqi Kurdistan or smuggled from Turkey or other parts of Syria, but expensive in every case.

Rojava started cementing its achievements during 2017, as the fight against the pseudo-state of ISIS became more likely to come to an end and the regime recaptured vast areas. In July 2017, the Syrian Democratic Council, the political wing of the SDF, decided to hold communal, local and parliamentary elections on 22 September, 3 November 2017 and 1 January 2018, respectively, which the Syrian deputy foreign minister called a "joke". ${ }^{69}$ These elections, however, were postponed due to the fighting, and have not been organized to date.

62 Baher, Z. "The Experiment of West Kurdistan Has Proved That People Can Make Changes"

63 Lebsky. "The Economy of Rojava"

64 Yousef, A. "The Social Economy in Rojava". Kurdishquestion.com. 26 May 2015. http://kurdishquestion.com/ oldarticle.php?aid=the-social-economy-in-rojava, Accessed on 24 January 2020.

65 "A Mountain River Has Many Bends"

66 Lebsky. "The Economy of Rojava"

67 "A Mountain River Has Many Bends".

68 Khalaf. Governing Rojava. 19.

69 Barrington, L. "Elections in Kurdish-led areas will not divide Syria: minister". Reuters. 7 August 2017. https://www.reuters.com/article/us-mideast-crisis-syria-kurds/elections-in-kurdish-led-areas-will-not-divide-syria-minister-idUSKBN1AM0LM, Accessed on 24 January 2020. 


\section{ROJAVA SEEN FROM DAMASCUS}

On 15 September 2017, Buthania Shaaban, a political adviser to the Syrian President, openly stated that Syria considers the SDF an illegitimate force, similarly to the ISIS, and would fight until regaining control over the whole country. ${ }^{70}$ The statement came after the break of the siege of Deir Ez-Zor, one of the most important victories the Syrian Army has achieved since 2012, with significant Russian support though. ${ }^{71}$ Just a few days later, in the context of the then coming referendum on independence in Iraqi Kurdistan, Syrian foreign minister Walid al-Moualem expressed Damascus' readiness to negotiate with the Kurds about the demanded autonomy within Syria once the war against ISIS was over. ${ }^{72}$ These statements show some confusion; revealing that the relation between Damascus and Rojava was ambiguous during the last years.

As Turkey showed serious intents to interfere into the events in Syria after the outbreak of the Arab Spring, Damascus became determined to keep its northern neighbour out. It offered citizenship to the Kurds deprived from that due to the Decree of 1962. However, as clashes intensified in other parts of the country, and the Syrian government realized that it had no sufficient forces to maintain power in the north, it searched for a local actor who was able to provide security but did not bring the territory out of the Syrian state, and was willing to prevent Turkish military from entering the country. After the President-ordered killing of Mashaal Tammo, ${ }^{73}$ founder and fellow activist of the Kurdish Future Movement Party, a vocal critic of the Syrian President and, more importantly, the Kurdish collaborator of the Turkey-backed opposition, the Syrian National Coalition (SNC), local power in northern Syria shifted to the PYD. The Syrian regime not only had some experience of cooperation with the PYD due to its connection to the PKK, but there had also existed a complementary activity between them, for instance the PYD helped to crack down on Kurdish anti-regime demonstrators in Afrin in early 2012, for its own interest which, however, coincided with that of the regime. ${ }^{74}$

The first town abandoned by the Syrian administration was Kobanî on 19 July 2012, followed by several others in the following days. The government forces withdrew without resistance, while the YPG prevented the rebelling Free Syrian Army (FSA) from entering the towns. During those months, the Syrian Army, YPG, FSA, and ISIS were all present in what later became Rojava. Clashes between YPG and the Syrian Army were sporadic; the first one occurred on 21 July 2012, just two days after the start of the withdrawal, in Qamishlo.

70 Hamidi, I. "Head of Kurdish People's Protection Units: Damascus Declared War against us". Asharq Al-Awsat, 17 September 2017. https://aawsat.com/english/home/article/1026421/head-kurdish-peoples-protection-unitsdamascus-declared-war-against-us, Accessed on 24 January 2020.

71 The Russian support has long been vital for the survival of the Ba'ath Party regime. First, after signing an agreement on the Soviet (Russian) use of Tartus naval base in 1972, the Soviet Union helped to quell the majority Sunni insurgency against the regime by the early 1980s. Second, the Russian military intervention into the Syrian civil war in September 2015 clearly saved the regime from failing. On the history of Russian-Syrian partnership see Van Benthuysen, J. "In-between anarchy and interdependence: from state death to fragile and failing states". Third World Quarterly 36/1. 2015. 32-34. DOI:10.1080/01436597.2015.976015

72 Jadallah, A. "Damascus Says Syrian Kurdish Autonomy Negotiable: Report”. US News. 26 September 2017. https:/www.usnews.com/news/world/articles/2017-09-26/damascus-says-syrian-kurdish-autonomy-negotiable-report, Accessed on 24 January 2020.

73 "Assad ordered killing of Kurdish activist Mashaal Tammo: Leaked files". Al Arabiya English. 10 October 2012. https://english.alarabiya.net/en/2012/10/10/Assad-ordered-killing-of-Kurdish-activist-Mashaal-TammoLeaked-files.html, Accessed on 24 January 2020.

74 Cagaptay. "Syria and Turkey: The PKK Dimension" 
The withdrawal was not complete: some area had been kept by the regime, the so called security boxes ${ }^{75}$ in Qamishlo and Hasakah, both important centres of Christian presence. ${ }^{76}$ Anti-regime rebels usually considered Christians and other minorities as supporters of the regime and the mutual distrust between the sides led to the situation that the state had enough popular support to keep key positions in these areas, such as government buildings, border crossing points to Turkey, or the Qamishlo airport, even when the PYD/YPG seized the neighbouring regions. Similarly, the PYD was able to organize, and 'neutralize' the Kurdish populated Sheikh Maqsood neighbourhood in Aleppo amidst fierce confrontations between the rebels and government forces.

Since then, the relationship between the regime and Rojava mostly could have been described with expressions like mutual tolerance, even need sometimes, or live and let live, due to the parallel fight against the common enemies, the ISIS and Turkey. This mutual reliance paradoxically led to situations like the praising of the YPG for its fight against Islamists by President Al-Assad in January 2013, at the same time when he failed to provide support for the Syrian Army confronting the YPG attempting that time to dislodge Syrian forces from the Kurdish territories. ${ }^{77}$ There were rumours that in 2014, during the siege of Kobanî, the Syrian Army furnished the YPG with military support; however, the YPG denied this. ${ }^{78}$ Similarly, when the Syrian reconciliation minister visited Rojava in April 2015, he enunciated that Damascus would provide further support for "Kurdish forces to defeat the terrorist organization", and that there was no objection to the use of Kurdish flag if "everything remains within a united Syria". ${ }^{79}$ Last summer even presidential adviser Buthaina Shaban confirmed the weapon supply for the Kurdish forces when they had fought with ISIS, regretting that after joining efforts with the US, the SDF "lost contact with the regime". ${ }^{80}$

A new era came in early 2018, when Turkey attacked the Afrin region with ground forces. Although Turkish military interventions and their various consequences will be detailed in Chapter V, they made clear the mutual interest for cooperation between the Autonomous Administration of North and East Syria and Damascus to minimize Turkey and its allies' influence in Syria. The reason is not only the tangible Turkish military presence on Syrian soil, but also that Turkey aims to carry out long-term policies. After the Turkish invasion of Afrin, due to a settlement policy applied there by Turkey, the previously predominantly Kurdish-inhabited region turned into an ethnically mixed Kurdish-Arabic one. ${ }^{81}$ As men-

75 The two city centres with the bazaar and government buildings were kept by central administration and fortified by the regime security forces. In Qamishly, the airport also remained in the hands of Damascus.

76 Christians form around 10 percent of the population and traditionally have good cooperation with the Alawites, the backbone of the Assad-regime. Christians' rights were recognized by the 1973 Constitution and respected by the regime. They are overrepresented within state administration and armed forces.

77 Van Wilgenburg, W. "Kurdish Forces Clash with Main Syrian Opposition in Syria, Reports Say". Rudaw. 17 January 2013. https://web.archive.org/web/20130118175834/http://www.rudaw.net/english/news/syria/5666. html, Accessed on 24 January 2020.

78 “Syria Providing Military Support to Kurds in Battle Against ISIS”. Haaretz. 27 October 2014. http://www. haaretz.com/middle-east-news/1.623051, Accessed on 24 January 2020.

79 Behlewî, D. "Syrian minister: we are providing military, financial support to Kurdish fighters". Rudaw. 19 April 2015. http://www.rudaw.net/english/middleeast/syria/19042015, Accessed on 24 January 2020.

80 "Buthaina Shaban: We provided SDF with weapons". ARK. 2 September 2019. https://www.arknews.net/en/ node/12620, Accessed on 24 January 2020.

81 Izady, M. "Syria: Ethnic Shift 2010-mid 2018”. 2018. https://i.redd.it/umzbb3cu7lc21.png, Accessed on 24 January 2020 . 
tioned above, this region had been an important stronghold of the PKK in Syria, therefore weakening the Kurdish element there means decreasing the potential of the PKK.

Similarly to early 2018, another such cooperation between the Autonomous Administration of North and East Syria and Damascus was necessary in late 2019, when Turkey carried out another attack with ground forces 'to secure' the SDF-held areas just south to its border after the Trump administration ordered the withdrawal of the US forces from Rojava on 6 October 2019.

Despite the predominantly peaceful co-existence between the regional and the Syrian administrations, there were clashes between the sides first in the enclaves, later on the frontlines. For instance, in early 2013 the Syrian Army (SAA) attacked the YPG-held 'neutral' Sheikh Maqsood neighbourhood in Aleppo, when FSA fighters sought shelter there. In April 2016, fighting escalated in Qamishlo between local YPG and Syrian Army forces, after the Syrian forces started shelling a civilian neighbourhood as a response to an ISIS detonated car bomb in the town, and only the order of the top leaders of the two sides was able to ease the tensions. ${ }^{82}$

Just months later, in August 2016, fighting erupted between local YPG and government forces in Hasakah, where the Syrian Air Force had bombed Kurdish held territories for the first time since the beginning of the conflict. According to sources, the reason was the government's discontent with the Rojava call of disbanding the National Defence Force, the backbone of state presence in Hasakah. ${ }^{83}$ After several days of fighting with the Asayish, the regime forces lost the majority of the territory previously controlled in the town; however, since an agreement was reached between the sides, they were allowed to keep key government buildings in the centre.

In 2017, Soner Çağaptay, the political scientist of The Washington Institute for Near East Policy, identified four possible scenarios to which Rojava could be subjected, (1) the Transnistria model of a Russian vassal, (2) the Kosovo model of independence with partial recognition, (3) the Iraqi Kurdistan model of Turkish protection, and (4) the 1975 Algeria model of forced reintegration. ${ }^{84}$ It cannot be excluded that Damascus will try the fourth option; ${ }^{85}$ however, it is highly questionable whether Syria will have an opportunity and the capabilities for such a move.

The second and third Turkish military invasions in 2018 and 2019 respectively, detailed in Chapter V, have also resulted in decreasing chances for an easy solution. Furthermore, the planned weakening of the Kurdish majority, due to Turkish settlement policies detailed in

82 Sary, G. "Rojava's Tortuous Relationship to the Syrian Regime". LSE. 19 September 2016. http://blogs.lse. ac.uk/mec/2016/09/19/rojavas-tortuous-relationship-to-the-syrian-regime/, Accessed on 24 January 2020.

83 "Syrian regime forces bomb Kurds in north for first time". Hürriyet Daily News. 18 August 2016. http://www.hurriyetdailynews.com/syrian-regime-forces-bomb-kurds-in-north-for-first-time.aspx?page$\mathrm{ID}=238 \& \mathrm{nID}=102997 \&$ NewsCatID=352, Accessed on 24 January 2020.

84 Cagaptay, S. "Rojava's Future: Four Models Explained". The Washington Institute. 5 June 2017. http://www. washingtoninstitute.org/policy-analysis/view/rojavas-future-four-models-explained, Accessed on 24 January 2020.

85 In the 1970 peace accord between Baghdad and the Iraqi Kurds, Saddam Hussein was willing to give autonomy to the Kurdish region but the two sides could not agree on the question of Kirkuk. In 1974, the Iraqi Kurds restarted their struggle against the regime with Iranian and Israeli support. In response Saddam negotiated a deal with Iran (Algiers Agreement), leading Tehran to halt its support for Iraqi Kurdish groups. After that Saddam crushed the Kurdish revolt and forced his own version of autonomy on Kurdistan. Farouk-Sluglett, M. and Sluglett, P. Iraq Since 1958: From Revolution to Dictatorship. London: I.B. Tauris, 2001. 187-189. 
the next chapter, in the northern areas of Syria might seem to help also Damascus but it is predictable that any settlement will rather increase Turkey's influence in the region instead of that of Damascus, of course, at the expense of the SDF.

\section{TURKISH INVOLVEMENT - ROJAVA AS A THREAT FOR A NATO MEMBER STATE}

The Arab Spring in Syria posed Turkey a dilemma. During the preceding decade under the then Minister of Foreign Affairs Ahmet Davutoğlu, Turkey adopted the so called zero-problems foreign policy with its neighbours. The relations with Syria were cordial at least, starting even before the AKP era in Ankara. The two countries set aside their conflicts in 1998 when Damascus finally ended the presence of the PKK in Syria and forced Abdullah Öçalan to leave the country.

In the first months of 2011, the Erdoğan government tried to convince the Assad regime to react peacefully to the demonstrations and negotiate with Islamist and secular opposition fractions. By the summer of 2011, it became obvious that the Syrian government had no intention in sharing power, and both the demonstrators and regime became more violent. Both the Turkish approach to the Syrian conflict and Damascus' own reaction were heavily influenced by the Egyptian revolution and the Libyan civil war, where two long time dictators were deposed. In Ankara's understanding the fall of Hosni Mubarak and Moammer Qaddhafi indicated a similar fate for Bashar al Assad, hence Turkey threw its lot with the opposition.

Ankara had two objectives in the Syrian crisis. First, to support the opposition to overthrow the Assad regime, and second to contain the activities of any PKK related organization within Syria. In the first years of the civil war, Turkey focused on building up and equip the Free Syrian Army (FSA) with the assistance of Qatar and Saudi Arabia. Ankara also allowed foreigners to cross freely the country to join the armed opposition and jihadist groups in Syria. Most of the so called "foreign fighters" joined the Syrian al-Qaeda (Al Nusra Front) and Islamic State of Iraq and Syria (ISIS).

Until 2014 the Syrian Kurds received less attention from Ankara, mainly because they were internally weak, engaged in internal struggles and the opposition of the Assad regime in North Syria, rival to the YPG, had significant military power and international support. The situation changed at the siege of Kobanî as demonstrated in Chapter III. The military cooperation of the most powerful military of the world and the small non-state actor considered to be a terrorist organization rang the bell in Ankara, and from that moment the Turkey's attention started to increase towards the "Rojava issue". ${ }^{86}$ This was strengthened by the fact that from 2015, the YPG fought a two-fold campaign: while fighting according to US objectives to liberate Raqqa, the "capital" of ISIS, the now rebranded Syrian Democratic Forces also aimed to connect the Kurdish populated entities of Qamishlo, Kobanî, and Afrin. The Erdoğan government considered this a vital threat and by 2016 containing the YDG expansion had overshadowed even the previous top priority of Turkey in Syria: the overthrow of the Assad-regime.

86 Egeresi Z. "Törökország Szíria-politikájának változása: a föbb dinamikák”. KKI Elemzések 8. 2020. 9. https://kki.hu/wp-content/uploads/2020/01/08_KKI-elemzes_TUR-SYR_Egeresi_20200121.pdf, Accessed on 24 January 2020. 
For Ankara, the PYD/YPG is nothing more than an offshoot of the terrorist organization PKK. The threat of connecting YPG-controlled areas along the whole Turkish-Syrian border therefore triggered the first open Turkish military intervention in Syria on $24 \mathrm{Au}-$ gust 2016 ${ }^{87}$ During Operation Euphrates Shield, the Turkish forces and parts of the FSA occupied the last segments of the ISIS “border" area with Turkey, and separated definitely the Kurdish held territories of Afrin and Kobanî/Qamishlo. The occupation was not only a military move, Turkey had far-reaching plans with the region, therefore it started an alternative society building by the resettlement of Syrian Turkomans and establishing institutions there. ${ }^{88}$

In 2017, Turkey tried to expand its presence in Syria, moving both eastwards and westwards. The PYD intended to use conflicting interests of the international actors present on Syrian soil so when Turkish/FSA troops moved against Manbij to the West, the Kurds invited US troops to patrol in the Manbij area. When Turkish/FSA troops deployed against the city of Tell Rifaat to the East, the PYD invited Russia to act as a guarantor in the city and in the whole of Afrin canton in March 2017. ${ }^{89}$ Gradually Ankara became extremely frustrated by the PYD moves and understood the need to involve more the great powers (US and Russia) to be effective against the Syrian Kurds.

Early 2017, Turkey together with Iran and Russia launched the "Astana format" of negotiations, a new proposal to bring together the Assad regime and those Syrian opposition parties which were willing to negotiate a ceasefire. Coordinating with Moscow and Tehran made Ankara an almost equal partner in the Syrian civil war although Turkey backed forces fighting against the regime and thus Russia and Iran. The Erdoğan administration used its newfound influence to push for a new military offensive against the YPG, which coincided with the Syrian government's offensive against Eastern Ghouta, near Damascus.

Operation Olive Branch, the Turkish/FSA invasion of Kurdish-held Afrin canton, started on 20 January 2018. Damascus and Russia offered protection to the SDF if they handed over the region, but the Kurds refused the offer. By mid-March 2018, the SDF had been defeated and its forces withdrawn to other Kurdish-held areas. Tell Rifaat and the Menagh Air Base were handed over to the Syrian Army and Russian troops to prevent it falling into the hands of Turkish and FSA forces. ${ }^{90}$ Gradually, Operation Olive Branch turned into a humanitarian disaster; it led to the displacement of 150,000 people, ${ }^{91}$ mass human rights

87 Turkish President Erdoğan stated that Turkey should be protected against "the terrorist groups of Daesh and PYD that threaten our country in northern Syria". "Erdogan says Syria operation aimed at IS jihadists, Kurdish PYD”. Daily Mail Online, 24 August 2016. http://www.dailymail.co.uk/wires/afp/article-3756119/Erdogan-says-Syria-operation-aimed-IS-jihadists-Kurdish-PYD.html, Accessed on 24 January 2020.

88

Jarabulus border town under FSA control has been a show case: the town was connected to the Turkish electrical grid in September 2016, at the same time a new hospital was created there under the Turkish Ministry of Health, and in October 2017, the Turkish Post (PTT) opened a branch in the town.

89 Iddon, P. “The power plays behind Russia's deconfliction in Afrin”. Rudaw. 10 September 2017. https://www. rudaw.net/english/analysis/10092017, Accessed on 24 January 2020.

90 Russian forces were allowed to take over the airport even earlier, in October 2017. Illingworth, A. "Russian forces raise their flag above major Kurdish base in north Aleppo". Al-Masdar News. 22 October 2017. https:// www.almasdarnews.com/article/video-russian-forces-raise-flag-major-kurdish-base-north-aleppo/, Accessed on 24 January 2020.

91 “Syria: Humanitarian Fund series - 'Living here has taught me how strong I really am.'”. United Nation's Office for the Coordination of Humanitarian Affairs. 7 August 2019. https://www.unocha.org/story/syria-\%E2\%80\%9Ci-wonder-if-i-will-ever-go-home\%E2\%80\%9D, Accessed on 24 January 2020. 
violations against the remaining local population, ${ }^{92}$ and to the colonisation of the occupied territories by the Turkish forces. ${ }^{93}$ The Turkish province of Hatay emerged as responsible for overseeing the activities of the local councils in Afrin canton and for helping with providing basic services. As Syrian researcher Khayrallah al-Hilu explained: After a few months of giving the armed factions free rein, Turkey has supported military and civilian police forces in order to achieve relative security in the area. Indeed, Ankara has been able to pull strings in Afrin among the armed factions and military and civilian police, along with their various specialised departments. ${ }^{94}$

Until today, the last round of Turkish military involvement in Syria started in September 2019. By that time, the confrontation between Turkey and the US reached new heights: Ankara decided to purchase the Russian made S-400 Triumph missile system, while Washington removed Turkey from the F-35 fifth generation fighter program. The US Congress threatened the Erdoğan administration with sanctions, while the Turkish President lobbied several times with Donald Trump to pull out US troops from NES. The withdrawal of troops from foreign mission was one of the campaign promises of the US President, although this was contrary to his administration's declared policy.

The withdrawal of the US troops was debated for a longer period of time. US Secretary of State Mike Pompeo and Turkish Foreign Minister Mevlüt Çavuşoğlu announced a deal in June 2018 aiming at joint patrolling in Manbij area and the withdrawal of YPG forces. ${ }^{95}$ However, this agreement did not satisfy Turkey because it did not solve the problem of YPG presence along the Turkish-Syrian border. From Turkey's perspectives: Ankara's primary objective is to create a militarily protected safe zone that will be liberated from terrorist-designated YPG-entities, prevent the YPG's territorial continuity in the eastern part of the Euphrates River, and then open up a territorial zone to protect Turkey's border against, according to the Turkish narrative, any terrorist infiltration. The area mentioned is $40 \mathrm{~km}$ deep, $550 \mathrm{~km}$ long and harbours 22 US military bases. ${ }^{96}$

While Washington and Ankara continued their negotiations on a future "safe zone" in the border area, Turkish President Erdoğan kept threatening with a military invasion of the region. US diplomacy finally averted a new conflict by agreeing with Turkey on a new proposal regarding the territory between the Tigris and Euphrates rivers on 7 August 2019.

92 "Between a Rock and a Hard Place - Civilians in North-western Syria". United Nations Human Rights Office of the High Commissioner. Monthly Human Rights Digest, June 2018. https://reliefweb.int/sites/reliefweb.int/ files/resources/ohchr___syria_monthly_human_rights_digest__june_2018.pdf, Accessed on 24 January 2020.

93 "The resettlement by the Turkish authorities continues to the people who have been displaced towards the Syrian North and more than 40 thousand persons have been settled in houses and Camps in Afrin area". Syrian Observatory for Human Rights. 11 May 2018. http://www.syriahr.com/en/?p=91846\&_cf_chl_ jschl_tk_=aa9ab11cd4d91686579f6808f708f17185d0f2dc-1579954237-0-AdhCoes71czZcwpk6xLXNFRn5sboA_bSsFkTGv5h9g9N_PDMINzqp3q4ozEqzsCizMZNlgafqObApyVCiqkM1JHDzHtrw4Fo1xGhJYky5z3EjT2y_m-FHbcNjxrcfQaGbxMilJtBfkH8E6ElulazZeDGF0j-5dc5HSq6jdxlnducfcNxC2jpQ1ybhjqPiHWcjI39KuLMG1KwXRP7tHr-0XBrL0p40DAP2HCpAnfDv_DH9uo7dFK-KDgXfzvnSrpCNK6kcyzImKVnug2pENM4jGw, Accessed on 24 January 2020.

94 Al-Hilu, K. Afrin Under Turkish Control: Political, Economic and Social Transformations. San Domenico di Fiesole: European University Institute, 2019. 9. DOI:10.2870/136668, Accessed on 24 January 2020.

95 Kanat, K. B. and Hannon, E. J. "The Manbij Roadmap and the Future of U.S.-Turkish Relations". Middle East Policy 25/3. 2018. 111-123. DOI:10.1111/mepo.12365, Accessed on 3 January 2020.

96 Atmaca, N. "Safe Zones and Devil in Details: Turkey is Running out of Options". NATO Defence College. http://www.natofoundation.org/wp-content/uploads/2019/07/NDCF-Atmaca-Paper-260719-1.pdf, Accessed on 24 January 2020. 
The buffer zone ("safe zone") was to be $115 \mathrm{~km}$ long and $5 \mathrm{~km}$ deep. Between Tell Abyad and Ras Al-Ayn/Serakane, the depth of the buffer zone was extended to $14 \mathrm{~km}$. The YPG/ SDF agreed to evacuate the area and destroy all defensive positions. US and Turkish forces agreed to conduct joint patrol. ${ }^{97}$

A new crisis emerged when US forces were suddenly ordered to withdraw from NES on 6 October 2019. President Trump's decision was followed by a phone call to President Erdoğan, and also the commander of the SDF, Gen. Mazloum Kobani was informed about the decision. In the ensuing chaos Ankara ordered a limited incursion on a $100 \mathrm{~km}$ stretch between the towns of Tell Abyad and Ras Al-Ayn/Serakane. Like in the previous invasions, Operation Peace Spring included Turkish military forces and Syrian opposition groups under the umbrella "National Army", as well. On 15 October, a week after the beginning of the Turkish invasion, the PYD made a deal with the Syrian government. The Kurdish leadership had no other choice but to turn to Washington's foes to deter further Turkish incursion. ${ }^{98}$ While Ankara had largely achieved its objectives by that time, there were fears of further expansion of the previously declared $100 \mathrm{~km}$ wide and $30 \mathrm{~km}$ deep safe zone. Russian and Syrian forces deployed to SDF-held regions on three axis, to Manbij, Tell Tamr and Qamishlo. By the end of October 2019 hopes of NES had been shattered, the PYD and its militia lost its rule in the core Kurdish populated Syrian areas as seen on Map 3. Although President Trump's decision on the full withdrawal was partly reversed, both his Secretary of Defense Jim Mattis and his Special Envoy for the Global Coalition to Counter ISIL, Brett McGurk resigned in protest. ${ }^{99}$

The third Turkish military invasion resulted in mass displacement again, according to estimations around 300,000 people left the area, and Turkish and allied forces again committed mass human rights violations. ${ }^{100}$ What is even more worrying is the Turkish President's plan to change the ethnic makeup of northern Syria along the border with Turkey for so-called security reasons. According to Ankara's plan, around 1 million refugees would be settled into 140 villages in the 20-mile-deep area it controls in Northern Syria, in the framework of a reconstruction program requiring more than $\$ 26$ billion in foreign assistance. ${ }^{101}$ The implementation of the program, obviously leading to the ethnic reengineering of the region, has already started. ${ }^{102}$

${ }^{97}$ Ant, O. "Turkey, U.S. Reach Agreement on Creating Buffer Zone in Syria”. Bloomberg. 7 August 2017. https://www.bloomberg.com/news/articles/2019-08-07/turkey-s-akar-says-syria-talks-with-u-s-were-positiveanadolu, Accessed on 24 January 2020.

${ }^{98}$ Ibrahim, A. "Syria's Kurds forge 'costly deal' with al-Assad as US pulls out". Al Jazeera, 15 October 2019. https://www.aljazeera.com/news/2019/10/pullout-syria-kurds-costly-deal-assad-191015122222288.html, Accessed on 24 January 2020.

${ }^{99}$ Cooper, H. “Jim Mattis, Defense Secretary, Resigns in Rebuke of Trump's Worldview”. The New York Times, 20 December 2018. https://www.nytimes.com/2018/12/20/us/politics/jim-mattis-defense-secretary-trump.html, Accessed on 24 January 2020.

100 "Syria: Damning evidence of war crimes and other violations by Turkish forces and their allies". Amnesty International. 18 October 2019. https://www.amnesty.org/en/latest/news/2019/10/syria-damning-evidence-ofwar-crimes-and-other-violations-by-turkish-forces-and-their-allies/, Accessed on 24 January 2020.

${ }^{101}$ Lynch, C. and Seligman, L. "Turkey Pitches Plan to Settle 1 Million Refugees in Northern Syria". Foreign Policy, 18 December 2019. https:/foreignpolicy.com/2019/12/18/turkey-pitches-plan-settle-1-million-refugees-northern-syria-erdogan-kurds/, Accessed on 24 January 2020.

102 “Turkey starts construction of refugee settlements in Syria, Erdoğan says". Ahval. 16 January 2020. https://ahvalnews.com/turkish-foreign-policy/turkey-starts-construction-refugee-settlements-syria-erdogan-says, Accessed on 24 January 2020. 


\section{CONCLUSION - WHAT FUTURE FOR ROJAVA?}

The Middle East, where due to geopolitics a region called Rojava, now officially Autonomous Administration of North and East Syria emerged after 2012, has long been an instable region. The Kurdish-based entity used the opportunity the withdrawal of the Syrian administration and military presented and brought into light its already working clandestine institutions. With the ongoing international war against ISIS in the following years, the importance of the Kurdish fighters rose offering them the possibility to build society based on ideas extremely different from every other in the region.

The PYD, the leading force behind the transformation of Syrian Kurdistan, has been following a distinct leftist political programme inherited from Abdullah Öçalan and his organization, the PKK. This political vision differs from how Arab Nationalism, Islamism and Zionism intend to build society. Although secularism and socialist ideas are well-known in the Middle East, the equality of women and the egalitarian nature of economy (the existence of cooperatives and communes) create a significant difference in comparison to the Muslim countries. Furthermore, the recognition of the multi-ethnic and multi-religious nature of society and the lack of a nationalist discourse separates Rojava from almost every country in the region, including Israel.

Politically, Rojava is not a plural democracy since governance is based on political exclusion; however, one of the core ideas is ethnic inclusion. Political exclusion ensures the required internal stability during the time of the fight against external threats, such as ISIS or Turkey, but after an eventual ceasefire it could impede the creation of a proper inclusive democracy, which Rojava has been trying to portray itself. Yet, the sustainability of a democratic Kurdish or at least multi-ethnic state in the Middle East is problematic in itself, should peace come without political pluralism, the Rojava experience could turn into a failure.

Geopolitics has traditionally been influencing the fate both of the Kurds and Rojava. Shifting geopolitical balance allowed the PYD to create its self-proclaimed autonomous region in 2012, and to increase its territory between 2012 and 2017, but it also resulted in significant throwbacks and a loss of territory in the past years. The Syrian Kurds have experienced bitter disappointments: both Russia and the US sacrificed Kurdish interests for their own geopolitical goals. The fall of ISIS resulted in a more determined Turkey stepping up against Rojava: since 2016, there have been three ground military operations resulting in significant decrease of the SDF-held territories and weakening their heartland. Nevertheless, Rojava's existence is still a necessity for the international community, which leads to a joint interest in not letting Turkey conquering the whole of the territory the PYD has, and to cooperation between the SDF and the US and Russia simultaneously, despite the latter two being opponents in Syria.

The ongoing Syrian conflict has reshaped the ethnic composition of Syria, yet the case of the Afrin region is particular: with settling Arabs there, the Turkish invaders intentionally decreased the share of the Kurds in a previously predominantly Kurdish, and especially PKK-supporting territory. This ethnic re-engineering might have far-reaching consequences, as it is hardly likely that Turkey will ever allow the recreation of the previous Kurdish stronghold there. Such an ethnic re-engineering might not be the case in the territories occupied in late 2019, where the majority was Arab even before the outbreak of the Civil War. Nevertheless, we cannot exclude that there will be more Turkish attacks against still SDF/ YPG-controlled territories where similar problems could occur as in Afrin. 
The future of Syria itself is obscure, and so is that of Rojava. It is certain that an independent Kurdish state might not break away from either one or more countries in the Middle East soon, if ever. Deepening cooperation between Rojava and the Syrian regime for a united Syria and for the least possible Turkish influence in it could be more viable. Such cooperation, with strong international pressure and appropriate guarantees for Turkey, eventually could lead to the withdrawal of the Turkish ground forces from Syria on the long run, which is a common interest of Damascus and the Autonomous Administration of North and East Syria. Yet, geopolitics and the actual stance of the Syrian Civil War make such a withdrawal-scenario currently highly unlikely. What is more probable is that Rojava gradually becomes more and more reliant on the Syrian regime, however, due to the existence of the US Army bases in the region and the inadequate resources the Syrian regime has, it will be able to maintain its separateness. International economic and military interests also make this scenario probable; however, as we have seen, shifts in geopolitics easily make the future unpredictable in the Middle East.

\section{BIBLIOGRAPHY}

Al-Hilu, K. Afrin Under Turkish Control: Political, Economic and Social Transformations. San Domenico di Fiesole: European University Institute, 2019. DOI:10.2870/136668, Accessed on 24 January 2020.

Allsopp, H. The Kurds of Syria. Political Parties and Identity in the Middle East. I.B. Tauris, 2015.

“A Mountain River Has Many Bends”. Tangled Wilderness. 13. March 2015. http://www.tangledwilderness.org/a-mountain-river-has-many-bends/, Accessed on 24 January 2020.

Al-Wasl, Z. "PYD Refuses UNICEF Proposal to Administer 2,000 Schools in Hassakeh". The Syrian Observer. 8 September 2017. https://syrianobserver.com/EN/news/22370/pyd_refuses_unicef_ proposal_administer_schools_hassakeh.html, Accessed on 24 January 2020.

Anderson, B. Imagined Communities. London, New York: Verso, 2006.

Ant, O. "Turkey, U.S. Reach Agreement on Creating Buffer Zone in Syria". Bloomberg. 7 August 2017. https:/www.bloomberg.com/news/articles/2019-08-07/turkey-s-akar-says-syria-talkswith-u-s-were-positive-anadolu, Accessed on 24 January 2020.

“Assad ordered killing of Kurdish activist Mashaal Tammo: Leaked files". Al Arabiya English. 10 October 2012. https://english.alarabiya.net/en/2012/10/10/Assad-ordered-killing-of-Kurdish-activist-Mashaal-Tammo-Leaked-files.html, Accessed on 24 January 2020.

Atmaca, N. "Safe Zones and Devil in Details: Turkey is Running out of Options". NATO Defence College. http://www.natofoundation.org/wp-content/uploads/2019/07/NDCF-Atmaca-Paper-260719-1.pdf, Accessed on 24 January 2020.

Ayboğa, E. "The new justice system in Rojava". 13 October 2014. http://www.biehlonbookchin.com/ justice-system-in-rojava/, Accessed on 24 January 2020.

Baher, Z. "The Experiment of West Kurdistan Has Proved That People Can Make Changes" Co-operation in Mesopotamia. 12 March 2016. https://cooperativeeconomy.info/the-experiment-of-westkurdistan-has-proved-that-people-can-make-changes/, Accessed on 24 January 2020.

Barrington, L. "Elections in Kurdish-led areas will not divide Syria: minister". Reuters. 7 August 2017. https://www.reuters.com/article/us-mideast-crisis-syria-kurds/elections-in-kurdish-led-areas-will-not-divide-syria-minister-idUSKBN1AM0LM, Accessed on 24 January 2020.

Baumstieger, M. “Rojda Felat”. Süddeutsche Zeitung, 8 November 2016. http://www.sueddeutsche.de/ politik/profil-rojda-felat-1.3239571, Accessed on 24 January 2020. 
Behlewî, D. "Syrian minister: we are providing military, financial support to Kurdish fighters". Rudaw. 19 April 2015. http://www.rudaw.net/english/middleeast/syria/19042015, Accessed on 24 January 2020.

"Between a Rock and a Hard Place - Civilians in North-western Syria". United Nations Human Rights Office of the High Commissioner. Monthly Human Rights Digest, June 2018, https://reliefweb.int/ sites/reliefweb.int/files/resources/ohchr_-_syria_monthly_human_rights_digest_-_june_2018. pdf, Accessed on 24 January 2020.

"Buthaina Shaban: We provided SDF with weapons". ARK. 2 September 2019. https://www.arknews. net/en/node/12620, Accessed on 24 January 2020.

Cagaptay S. "Syria and Turkey: The PKK Dimension". The Washington Institute. 5 April 2012. http:// www.washingtoninstitute.org/policy-analysis/view/syria-and-turkey-the-pkk-dimension, Accessed on 24 January 2020.

Cagaptay, S. "Rojava's Future: Four Models Explained". The Washington Institute. 5 June 2017. http://www.washingtoninstitute.org/policy-analysis/view/rojavas-future-four-models-explained, Accessed on 24 January 2020.

Cooper, H. "Jim Mattis, Defense Secretary, Resigns in Rebuke of Trump's Worldview". The New York Times, 20 December 2018. https://www.nytimes.com/2018/12/20/us/politics/jim-mattis-defense-secretary-trump.html, Accessed on 24 January 2020.

Drwish, S. M. “Suriye'nin ilk Kürt üniversitesi tartışmalara neden oluyor”. Al-Monitor. 18 May 2016. http:// al-monitor.com/pulse/tr/originals/2016/05/kurds-rojava-afrin-first-university-ideology-ocalan.html, Accessed on 24 January 2020.

Echagüe, A. "The United States: redefining engagement?”. In Kausch, K. (ed), Geopolitics and Democracy in the Middle East. Madrid: FRIDE, 2015. 181-193.

Egeresi Z. “Törökország Szíria-politikájának változása: a föbb dinamikák”. KKI Elemzések 8. 2020. https://kki.hu/wp-content/uploads/2020/01/08_KKI-elemzes_TUR-SYR_Egeresi_20200121. pdf, Accessed on 24 January 2020.

"Efrîn Economy Minister Yousef: Rojava challenging norms of class, gender and power". DIHA. 22 December 2014. http://diclenews.com/en/news/content/view/436354, Accessed on 24 January 2020.

"Erdogan says Syria operation aimed at IS jihadists, Kurdish PYD”. Daily Mail Online, 24 August 2016. http:/www.dailymail.co.uk/wires/afp/article-3756119/Erdogan-says-Syria-operation-aimedIS-jihadists-Kurdish-PYD.html, Accessed on 24 January 2020.

Erkoyun, E. "Turkish university to open faculties in northern Syria”. Reuters. 4 October 2019. https:// www.reuters.com/article/us-syria-security-turkey-education-idUSKBN1WJ0Z3, Accessed on 24 January 2020.

Evran, S. "Efrin Is Being Rebuilt, Calls For Support And Investment” The Rojava Report. 6 May 2014. https://rojavareport.wordpress.com/2014/05/06/efrin-is-being-rebuilt-calls-for-support-and-investment/, Accessed on 24 January 2020.

Farouk-Sluglett, M. and Sluglett, P. Iraq Since 1958: From Revolution to Dictatorship. London: I.B. Tauris, 2001.

"Global powers seek to revive diplomatic process". The Economist, 12 February 2016. http://country.eiu.com/article.aspx?articleid=1363937520\&Country=Syria\&topic=Politics, Accessed on 24 January 2020.

Gorgas, J. T. "Les territoires de marge de la Syrie mandataire : le mouvement autonomiste de la Haute Jazîra, paradoxes et ambiguïtés d'une intégration « nationale » inachevée (1936-1939)". Revue des mondes musulmans et de la Méditerranée 2. 2009. DOI:10.4000/remmm.6481, Accessed on 24 January 2020. 
Hamidi, I. "Head of Kurdish People's Protection Units: Damascus Declared War against us". Asharq Al-Awsat, 17 September 2017. https://aawsat.com/english/home/article/1026421/head-kurdishpeoples-protection-units-damascus-declared-war-against-us, Accessed on 24 January 2020.

Hassan, H. "The Battle for Raqqa and the Challenges after Liberation" CTC Sentinel 10/6. 2017. 1-10.

Ibrahim, A. "Syria's Kurds forge 'costly deal' with al-Assad as US pulls out". Al Jazeera, 15 October 2019. https://www.aljazeera.com/news/2019/10/pullout-syria-kurds-costly-deal-assad-191015122222288.html, Accessed on 24 January 2020.

Iddon, P. "The power plays behind Russia's deconfliction in Afrin". Rudaw. 10 September 2017. https://www.rudaw.net/english/analysis/10092017, Accessed on 24 January 2020.

Illingworth, A. "Russian forces raise their flag above major Kurdish base in north Aleppo". Al-Masdar News. 22 October 2017. https://www.almasdarnews.com/article/video-russian-forces-raise-flagmajor-kurdish-base-north-aleppo/, Accessed on 24 January 2020.

“Interim local council established in Syria’s Afrin”. Hürriyet Daily News, 12 April 2018. http://www. hurriyetdailynews.com/interim-local-council-established-in-syrias-afrin-130227, Accessed on 24 January 2020.

Izady, M. "Syria: Ethnic Shift 2010-mid 2018”. 2018. https://i.redd.it/umzbb3cu7lc21.png, Accessed on 24 January 2020.

Jadallah, A. "Damascus Says Syrian Kurdish Autonomy Negotiable: Report". US News. 26 September 2017. https://www.usnews.com/news/world/articles/2017-09-26/damascus-says-syrian-kurdish-autonomy-negotiable-report, Accessed on 24 January 2020.

Kanat, K. B. and Hannon, E. J. "The Manbij Roadmap and the Future of U.S.-Turkish Relations". Middle East Policy 25/3. 2018. 111-123. DOI:10.1111/mepo.12365, Accessed on 3 January 2020.

Khalaf, R. M. Governing Rojava: Layers of Legitimacy in Syria. London: Chatham House, 2016. https://www.chathamhouse.org/sites/default/files/publications/research/2016-12-08-governing-rojava-khalaf.pdf, Accessed on 24 January 2020.

"Kurdish (Kurdî / (ىدروك)". Omniglot. https://www.omniglot.com/writing/kurdish.htm, Accessed on 24 January 2020.

"Kurdish Language". The Kurdish Project. https://thekurdishproject.org/history-and-culture/kurdish-culture/kurdish-language/, Accessed on 24 January 2020.

Lebsky, M. "The Economy of Rojava". Co-operation in Mesopotamia. 14 March 2017. https://cooperativeeconomy.info/the-economy-of-rojava/, Accessed on 24 January 2020.

Lynch, C. and Seligman, L. "Turkey Pitches Plan to Settle 1 Million Refugees in Northern Syria". Foreign Policy, 18 December 2019. https://foreignpolicy.com/2019/12/18/turkey-pitches-plan-settle-1-million-refugees-northern-syria-erdogan-kurds/, Accessed on 24 January 2020.

"Manbij Democratic Civilian Administration Council takes office". ANF News. 12 March 2017. https:// anfenglish.com/news/manbij-democratic-civilian-administration-council-takes-office-18957, Accessed on 24 January 2020.

McDowall, D. A Modern History of the Kurds. London, New York: I.B. Tauris, 2007.

"Member of the Kurdish Future Movement arrested by Kurdish Self-management forces in al Darbasiya city in Hasaka governorate on April 1". Syrian Network for Human Rights. 1 April 2017. http://sn4hr.org/blog/2017/04/01/member-kurdish-future-movement-arrested-kurdish-self-management-forces-al-darbasiya-city-hasaka-governorate-april-1/, Accessed on 24 January 2020.

"News Transcript of the Department of Defense Press Briefing by Gen. Townsend via teleconference from Baghdad, Iraq”. US Department of Defence. 1 March 2017. https://www.defense.gov/News/ Transcripts/Transcript-View/Article/1099469/department-of-defense-press-briefing-by-gentownsend-via-teleconference-from-ba/, Accessed on 24 January 2020. 
"Persecution and Discrimination against Kurdish Citizens in Syria". Office of the United Nations High Commissioner for Human Rights. http://lib.ohchr.org/HRBodies/UPR/Documents/session12/SY/ KIS-KurdsinSyria-eng.pdf, Accessed on 24 January 2020.

Safran, W. "Spatial and Functional Dimensions of Autonomy: Cross-national and Theoretical Perspectives". In Safran, W. and Máiz, R. (eds), Identity and Territorial Autonomy in Plural Societies. London, Portland: Frank Cass, 2000. 11-34.

Sary, G. "Rojava's Tortuous Relationship to the Syrian Regime". LSE. 19 September 2016. http:// blogs.lse.ac.uk/mec/2016/09/19/rojavas-tortuous-relationship-to-the-syrian-regime/, Accessed on 24 January 2020.

"SDF creates female Arab battalion in eastern Syria to fight patriarchy and ISIS". Al Shahid. 12 July 2017. https://alshahidwitness.com/sdf-female-arab-battalion-eastern-syria/, Accessed on 24 January 2020.

Sido, K. "Rojava - a protection zone for religious and ethnic minorities in northern Syria?". Gesellschaft für bedrohte Völker. June 2016. https://www.gfbv.de/fileadmin/redaktion/Reporte_ Memoranden/2016/Northern-Syria-research-trip-2016.compressed.pdf, Accessed on 24 January 2020.

Souleiman, D. "Syriacs protest Kurdish authorities over Syria school curriculum". Yahoo News. 12 September 2018. https://news.yahoo.com/kurds-christians-split-over-syria-school-curriculum-041427147.html, Accessed on 24 January 2020.

"Syria: Damning evidence of war crimes and other violations by Turkish forces and their allies". Amnesty International. 18 October 2019. https://www.amnesty.org/en/latest/news/2019/10/syria-damning-evidence-of-war-crimes-and-other-violations-by-turkish-forces-and-their-allies/, Accessed on 24 January 2020.

"Syria: Humanitarian Fund series - 'Living here has taught me how strong I really am.". United Nation's Office for the Coordination of Humanitarian Affairs. 7 August 2019. https://www.unocha.org/story/syria-\%E2\%80\%9Ci-wonder-if-i-will-ever-go-home $\%$ E2\%80\%9D, Accessed on 24 January 2020.

"Syria Providing Military Support to Kurds in Battle Against ISIS". Haaretz. 27 October 2014. http:// www.haaretz.com/middle-east-news/1.623051, Accessed on 24 January 2020.

"Syria-The Silenced Kurds". Human Rights Watch Reports 8/4. 1996. https://www.hrw.org/reports/1996/Syria.htm, Accessed on 24 January 2020.

"Syria: Turkey must stop serious violations by allied groups and its own forces in Afrin." Amnesty International. 2 August 2018. https://www.amnesty.org/en/latest/news/2018/08/syria-turkey-muststop-serious-violations-by-allied-groups-and-its-own-forces-in-afrin/, Accessed on 24 January 2020.

"Syrian regime forces bomb Kurds in north for first time". Hürriyet Daily News, 18 August 2016. http://www.hurriyetdailynews.com/syrian-regime-forces-bomb-kurds-in-north-for-first-time.aspx?pageID=238\&nID=102997\&NewsCatID=352, Accessed on 24 January 2020.

Tejel, J. Syria's Kurds: History, Politics and Society. London, New York: Routledge Taylor \& Francis Group, 2009.

"The Feyli Kurds of Iraq", https:/ethnicgeography.wordpress.com/2013/10/07/the-feyli-kurds-part-3the-feyli-kurds-of-iraq/, Accessed on 24 January 2020.

"The Kurdish language". Kurdistan Regional Government. http://cabinet.gov.krd/p/p.aspx$? 1=12 \& p=215$, Accessed on 24 January 2020.

"The resettlement by the Turkish authorities continues to the people who have been displaced towards the Syrian North and more than 40 thousand persons have been settled in houses and Camps in Afrin area". Syrian Observatory for Human Rights. 11 May 2018. http://www.syri- 
ahr.com/en/?p=91846\&_cf_chl_jschl_tk__=aa9ab11cd4d91686579f6808f708f17185d0f2dc-1579954237-0-AdhCoes71czZcwpk6xLXNFRn5sboA_bSsFkTGv5h9g9N_PDM1Nzqp3q4ozEqzsCizMZNlgafqObApyVCiqkM1JHDzHtrw4Fo1xGhJYky5z3EjT2y_m-FHbcNjxrcfQaGbxMilJtBfkH8E6ElulazZeDGF0j-5dc5HSq6jdxlnducfcNxC2jpQ1ybhjqPiHWcjI39KuLMG1KwXRP7tHr-0XBrL0p40DAP2HCpAnfDv_DH9uo7dFK-KDgXfzvnSrpCNK6kcyzImKVnug2pENM4jGw, Accessed on 24 January 2020.

"They freed a Syrian town from ISIS. Now they have to govern it". The Washington Post, 30 October 2015. https://www.washingtonpost.com/world/the-challenges-of-governing-after-theislamic-state/2015/10/30/8985938c-7673-11e5-a5e2-40d6b2ad18dd_story.html?utm_ter$\mathrm{m}=.5833 \mathrm{e} 928052 \mathrm{~b}$, Accessed on 24 January 2020 .

"Turkey starts construction of refugee settlements in Syria, Erdoğan says". Ahval. 16 January 2020. https://ahvalnews.com/turkish-foreign-policy/turkey-starts-construction-refugee-settlements-syria-erdogan-says, Accessed on 24 January 2020.

Van Benthuysen, J. "In-between anarchy and interdependence: from state death to fragile and failing states". Third World Quarterly 36/1. 2015. 22-39. DOI:10.1080/01436597.2015.976015

Van Wilgenburg, W. "Kurdish Forces Clash with Main Syrian Opposition in Syria, Reports Say". Rudaw. 17 January 2013. https://web.archive.org/web/20130118175834/http://www.rudaw.net/ english/news/syria/5666.html, Accessed on 24 January 2020.

Van Wilgenburg, W. "Young female mayor breaks boundaries in Syrian town freed from Islamic State". Middle East Eye. 1 July 2016. http://www.middleeasteye.net/in-depth/features/youngfemale-mayor-breaks-boundaries-syrian-town-freed-552711157, Accessed on 24 January 2020.

Vanly, I. Ch. "The Kurds in Syria and Lebanon". In Kreyenbroek, Ph. G. and Sperl, S. (eds), The Kurds: A Contemporary Overview. London, New York: Routledge, 2005. 112 - 134.

Yousef, A. "The Social Economy in Rojava”. Kurdishquestion.com. 26 May 2015. http://kurdishquestion.com/oldarticle.php?aid=the-social-economy-in-rojava, Accessed on 24 January 2020. 